\title{
НАСЛОВ ТЕМЕ НА МАТЕРЊЕМ ЈЕЗИКУ: ВИШЕЈЕЗИЧНЕ ДИГИТАЛНЕ БИБЛИОТЕКЕ
}

\section{Сажетак}

Језик је од кључног значаја за премост јаза између култура и нуди могућност за међународну сарадњу. Вишејезичне дигиталне библиотеке, које омогућавају корисницима да приступе дигиталним колекције користећи различите језике, дају портал за јачање индивидуалних култура, промовисање различитости, и побољшање глобалне информационе инфраструктуре истицањем незаступљених језике у световним заједницама.

Овај чланак испитује вишејезичне дигиталне библиотеке: Пројекат Гутенберг, Библиотека Еуропеана, дЛибра, еБиблиотека Гете-Институт Београд, Дигитална Народна библиотека Србије, Дигитална Библиотека Матице српске. Ово испитивање користи оквир изведен из дигиталне евалуације библиотечке праксе. Мисија, циљеви, финансирање, партнери, корисници, колекције, услуге и технологије ових дигиталних библиотека су анализирани да представе своје кључне вишејезичности функције.

Кључне речи: дигитална библиотека, е-филологија, пројекти, збирке, електронске библиотеке

\section{Увод}

Вишејезична библиотека - корак ка дијалогу различитих култура једног друштва.

„Језик је основ комуникације међу људима, као и део њиховог културног наслеђа. У многим људима језик изазива далекосежне емотивне и културне асоцијације и представља вредности које су укорењене у њиховом књижевном, историјском, филозофском и образовном наслеђу. Због тих разлога језик корисника не би требало да им буде препрека до мултикултурног наслеђа које је доступно у сајбер простору. Стога је складан развој информатичког друштва могућ само ако се подстиче доступност вишејезичних и мултикултурних информација.“ 
Интернет није једнојезичан и све је више садржаја који нису на енглеском језику, као и корисника Интернета који се не служе енглеским језиком. Удео разних језика се потпуно променио током последњих десет година. „Онлајн популација“ (особе које имају приступ Интернету) се 1996. састојала од четрдесет милиона оних којима је енглески матерњи језик и десет милиона оних којима није, док се 2005. онлајн популација повећала на двеста осамдесет милиона људи из прве групе и, чак, 680 милиона из друге (Voldering и Ljubanović 23).

Карактеристике корисника Интернета су се такође радикално промениле: од првенствено академског коришћења дошло се до широко распрострањеног коришћења у комерцијалне, образовне, забавне сврхе, као и коришћења у доколици. Оба правца развоја - промена језичког удела и промена карактеристика корисника-значе повећани притисак да се обезбеди приступ информацијама без језичких и културних препрека и рађају потребу за вишејезичним приступом информацијама. Библиотеке никада нису биле једнојезичне, ни у погледу грађе коју су набављале нити у погледу корисника. Ово је још тачније од када оне нуде своје каталоге и услуге преко Интернета.

Дигитална библитотека, електронска библиотека, виртуелна библиотека, хибридна библиотека, библиотека без зидова, универзална библиотека - низ је нових термина који су се појавили у последњој деценији. Значење библиотеке током векова прешло је дуг пут, од њеног оригиналног етимолошког значења „колекције књига”, до њеног данашњег значења колекције врло разноврсних информационих ресурса у савременом смислу речи, на пример чак и колекције софтверских пакета или метадата података. Свака традиционална библиотека представља засебну и особену целину, различиту од других библиотека. И свака дигитална библиотека такође представља јединствену целину, различиту од других дигиталних библиотека.

Језик је од кључног значаја да се премости јаз између култура и нуди прозор за међународну сарадњу. Као средство за размишљање и комуникацију, језик се манифестује у културном идентитету. Вишејезичне дигиталне библиотеке, које омогућавају корисницима да приступе дигиталним колекцијама користећи различите језике, дају портал за јачање индивидуалних култура, промовисању различитости, и побољшање глобалне информационе инфраструктуре истицањем незаступљених језика у световним заједницама. Они отварају могућности за шири међународни развој, разумевање и сарадњу. 
Вишејезичне дигиталне библиотеке пружају различите лингвистичке алате за приступ на мрежи. Међутим, мало је анализа или испитивање ових репозиторијума или њихових услуга. За истраживаче и програмере који су заинтересовани за изградњу вишејезичних дигиталних библиотека или обезбеђивање вишејезични приступ информацијама постојећим једнојезичним дигиталним библиотекама, важно је разумети кључне карактеристике постојећих вишејезичних дигиталних библиотека и њихове стратегије имплементације информација.

\section{Неке вишејезичне дигиталне библиотеке}

Светска дигитална библиотека (WDL - World Digital Library) ${ }^{1}$ је пројекат Америчке Конгресне библиотеке, који се спроводи уз подршку Уједињених нација за образовање, културу и науку (UNESCO), а у сарадњи са библиотекама, архивима, музејима, образовних институција и међународне организације из целог света. Светска дигитална библиотека чини доступним на Интернету, бесплатно и у вишејезичком формату, значајне примарне материјале из свих земаља и култура. Светска дигитална библиотека омогућава да се открију, истражују културна блага и значајна историјска документа на једном месту, на различите начине. Садржај на Светској дигиталној библиотеци обухвата књиге, рукописе, мапе, новине, часописи, фотографије, звучне записе и филмове.

Претраживо је по месту, времену, теми, језику и доприносу институције. Функција претраге се може користити за тражење све метаподатака и описима и пун текст штампаних књига на сајту.

Алати за навигацију, библиографске податке (такође познат као метаподаци), и описи садржаја су дати на седам језика: арапски, кинески, енглески, француски, португалски, руски и шпански. Метаподаци и описи могу да се слушају на опцији конверзије текста у глас који је на располагању за сваку ставку у свих седам интерфејса језика.

Партнери СДБ углавном су библиотеке, архиви, или друге институције које садржајима својих колекција који доприносе Светској

1 Светска дигитална библиотека, https://www.wdl.org/en/ (приступљено 25.02.2016) 
дигиталној библиотеци. Партнери могу обухватити институције, фондације и приватне компаније које доприносе пројекту и на друге начине, на пример дељење технологије или финансијски допринос. ${ }^{2}$

Европска библиотека (TEL - The European Library). ${ }^{3}$. Европске националне библиотеке поседују значајне конвенционалне и дигиталне колекције битне за научно и културно наслеђе. Како се глобална мрежа развија све брже, постаје све значајнија и расподела знања и усвајање заједничких стандарда. Спајањем информационих ресурса неких европских националних библиотека, идеја о јединственој европској националној библиотеци полако постаје део стварности. Нова европска виртуелна библиотека треба да омогући корисницима да претражују и приступају дигиталним и другим колекцијама из свих библиотека учесница у пројекту. Његов основни циљ јесте постављање темеља на којима ће после бити изграђен целокупни паневропски сервис. У пројекту је окупљено десет европских партнера, у форми конзорцијума, чији је задатак да објављује препоруке у погледу побољшања интероперабилности преко националних граница. Европска комисија финансира TEL као пропратни пројекат у оквиру широког подухвата и истраживачког програма Key Action 3 - Information Societies Technologies. Рад на пројекту официјелно је започет 1. фебруара 2001. године.

Националне библиотеке Европе основале су конзорцијум чији је задатак побољшање сарадње европских националних билиотека у погледу одржавања дигиталних и других колекција у будућности. Циљ јесте изградња кооперативног оквира који ће водити ка систему за приступ значајним националним и депозитним колекцијама (углавном дигиталним, али не искључујући ни папирне) у европским националним библиотекама. У оквиру пројекта TEL биће спроведена истраживања о моделима стварања мешовитих колекција традиционалних и електронских докумената, о могућностима приступа тим колекцијама на кохерентан начин и за локалног и за удаљеног корисника. TEL треба да допринесе изградњи научне и културне инфраструктуре у оквиру целе Европе кроз развијање приступа широком спектру различитих садржаја. TEL треба да понуди моделе информационе политике и развоја технолошке подршке за изградњу панев-

2 Партнери Светске дигиталнебиблиотеке, https://www.wdl.org/en/partners/ (приступљено 25.02.2016)

3 Европска библиотека, http://www.theeuropeanlibrary.org/tel4/ (приступљено 25.02. 2016) 
ропске дигиталне библиотеке која ће бити заснована на заједничком коришћењу ресурса и дигиталних колекција.

Од пројекта ће користи имати и оне европске библиотеке које још нису укључене у пројекат, стручњаци за информације који су ангажовани у сличним пројектима на националном нивоу, као и други информациони специјалисти, издавачи, доносиоци одлука, технички експерти, стручњаци за законе у области електронског издаваштва. Очекивани резултати јесу развој и тестирање отворених стандарда, радних метода и праксе која лако може да буде усвојена у свим националним библиотекама.

Европска библиотека је на више начина вишејезични сервис. Прво, може се одабрати интерфејс за претраживање на језику сваке библиотеке пуноправне чланице која своје метаподатке нуди за обједињено претраживање. Европска библиотека омогућава интерфејс на њихових десет језика: енглеском, немачком, француском, холандском, италијанском, финском, словеначком, српском, хрватском и португалском. Сваки нови текст - поруке помоћи, обавештења о грешци, привремене поруке, итд. постоје као матрица на енглеском језику, а именоване особе за контакт у свакој библиотеци пуноправној чланици треба да их преводе на своје матерње језике. Европска библиотека стреми истинској вишејезичности, и у вези са уносом термина за претраживање и са приказом резултата. То значи да се непрестано одвија борба са скуповима карактера, да би се поуздано омогућили различити уноси упита и исправан приказ резултата, са свим акцентима и другим дијакритичким знаковима који се користе у европским језицима. Вишејезично претраживање још није омогућено, али у току је више пројеката који се тиме баве, и њихови резултати ће бити примењени у Европској библиотеци када за то дође време. У наставку овог рада они ће бити поменути. Свака библиотека чланица CENL-а обавезна је да за овај део Европске библиотеке приложи податке у стандардизованом облику, на енглеском језику. Ако саме библиотеке могу да преведу ове информативне странице на француски и немачки, то се прима са захвалношћу. Сарадници чији су матерњи језици енглески, француски или немачки уређују текстове и јамче за исправност текстова и допуна.

Колекција Еуропеана (Europeana Collection) ${ }^{4}$, портал који се још назива и Европском дигиталном библиотеком, музејом и архивом,

4 Колекција Еуропеана, http://www.europeana.eu/portal/en (приступљено 26.02.2016) 
покренут је новембра 2008. године као прототип - пројекат Европске комисије, са циљем да се европско културно и научно наслеђе учини доступним корисницима интернета. Овај портал омогућава приступ великом броју дигитализованих јединица из различитих културноисторијских институција (библиотека, музеја, архива, аудио- видео архива и слично), а однедавно и садржај који уносе сами корисници (тзв. User-Generated Content, за сада само кроз пројекат Еуропеана 1914-1918). Еуропеана се финансира искључиво кроз истраживачке и остале програме и пројекте. Конзорцијуми - носиоци пројеката, које чине европске културно-историјске и научне институције, финансирају се од стране Европске комисије са циљем развоја технологија које је могуће применити на различите аспекте овог или других портала. Само у 2011. години финансирано је 37 оваквих пројеката, а до 2011. године прикупљено је 23 милиона дигиталних објеката, односно, њихових описа. Већина тих описа су септембра 2012. године објављени под ССО дозволом (The Creative Commons Zero ${ }^{5}$ ), што значи да су записи постали ослобођени аутор ских права. До 2012. године, већина средстава и напора били су усмерени на стварање ове критичне масе дигиталних објеката и уложен је новац у саму дигитализацију јединица. Од 2012. године стратегија пословања Еуропеане се мења, а напори се преусмеравају са дигитализације на промоцију портала и његово унапређење у смислу претраге и функционалности.

Народна библиотека Србије једна је од 329 институција чланица Еуропеана мреже и тренутно је укључена у пројекат под називом Europeana Collections 1914-1918 ${ }^{6}$ у којем је, заједноса 11 других значајних европских институција, своју грађу из Првог светског рата учинила доступном преко овог портала. Кроз овај пројекат, по први пут ће бити укључена и грађа из неких од српских архива и музеја у Еуропеану. У пројектима везаним за допринос садржају учеству је и Универзитетска библиотека „Светозар Марковић” са Europeana Newspapers ${ }^{7}$ који би требало да обезбеди више од 10 милиона но-

5 The Creative Commons, "CCO“, https://creativecommons.org/choose/zero/ (преузето 22.02.2016)

6 Europeana Collections 1914-1918, „About“, http://www.europeana-collections- 19141918.еи (преузето 22.02.2016)

7 Assocciation of European Research Libraries, "A Gateway to Europeana Newspapers", http://www.europeana-newspapers.eu (преузето 22.02.2016) 
винских страница и Europeana Libraries ${ }^{8}$, који ће донети дигиталне колекци је 19 европских водећих истраживачких библиотека у Еуропеану. Библиотека града Београда учествује у Europeana Awareness ${ }^{9}$ пројекту чији је главни циљ да промовише овај портал корисницима, потенцијалним финансијерима и институцијама које чувају културно наслеђе, ради побољшања коришћења и уноса садржаја, да се скрене пажња јавности на културно наслеђе и његов економски потенцијал, итд.

Корисници Еуропеане из читавог света сада могу приступати дигиталним објектима различитих колекција Библиотеке града Београда. Ове колекције располажу са 642 текстуална документа и 198 фотографија. Агрегација метаподатака се ради кроз пројекат LoCloud уз помоћ алата MORe. На овај начин постављена је основа која ће омогућити да и будући новододати дигитални објекти буду доступни на исти начин преко заједничког европског портала. Дигитална Библиотека града Београда је до сада имала више од 480.000 посета.

Међународнадечијадигиталнабиблиотека (ICDL-International Children's Digital Library $)^{10}$ садржи колекцију дечије књижевност, преко 10,000 књига на више од 100 језика, а библиотеци се може приступити на 11 јзика (Budzise-Weaver, Chen и Mitchell 223). Развијена је 2002. године средствима из Националне фондације за науку (NSF - National Scienece Foundation) и Институт за музејске и библиотечке услуге (IMLA - Institute for Museum and Library Services) као заједнички пројекат између Универзитета у Мериленду и Internet Archive. Намењена је деци, њиховим родитељима и другим одраслим истраживачима заинтересованих за дечију литературу. Занимљиво је да пројекат укључује децу као дизајн партнере и користи ову платформу за истраживање приступа вишејезичности (Budzise-Weaver, Chen и Mitchell 225).

Корисницимајеомогућенодачитајукњигенасвомидругимјезицима света, а приступ свим књигама је бесплатан. За претраживање базе није потребно ни отварање личног налога, мада постоји и та могућност, ако се одлучите да правите своју виртуелну полицу са омиљеним наслови-

8 Europeana Libraries, http://www.europeana-libraries.eu (преузето 22.02.2016)

9 Europeana Professional, "Europeana Awareness", http://pro.europeana.eu/project/europeana-awareness (приступљено 22.02.2016)

10 Међународна дечија дигитална библиотека, http://en.childrenslibrary.org (приступљено 26.02.2016) 
ма. Пошто је сајт намењен првенствено деци, и кретање унутар садржаја је поједностављено. Мали читаоци могу једноставно да кликну на иконицу „Read Books“ након чега је наслове књига могуће излистати на основу различитих категорија: узраст, дужина књиге, жанр, типови главних јунака, језик, чак и боја насловне странице.

Интерфејс омогућава корисницима четири опције за претрагу садржаја: једноставно претраживање, напредна претрага, претрага локације и претрага помоћу кључних речи. Када корисник кликне на линк „читај књиге“, интерфејс за једноставну претрагу пребацује на листу од 17 језика за интеракцију за претраживање садржаја. Једноставна претрага је претрага који нуди шарене иконе, избран списак књига, и „полицу са књигам“ за лакше кретање по колекцијама. Када корисник изабере језик, он или она може тражити књиге по боји, дужини, поглављима, сликама, ликовиа и темама. Напредна претрага омогућава кориснику да претражује по изгледу, садржини, врсти, предмету и публици (корисницма). Неке од конкретних тема из публике су старост, језик и датум издавања. Омогућена је и ппретрага по категорија као што су жанра, оцена публикације. Претрага локација је интерактивни глобус који омогућава кориснику да укаже и кликните на земљу (државу) коју желе да истражују. Ту је и текст верзија дестинација локација ако глобус не задовољава потребе корисника. Претрага помоћу кључнх речи је основни оквир за претраживање које укључује кратка упутства за тражење са додатком списка (падајући мени) свих доступних језика. Остале доступни карактеристике укључују за претраживање по листи свих доступних књига, аутору и илустратору, недавно додатих књига, награђене књиге, изложбе и активности (Budzise-Weaver, Chen и Mitchell 227).

Из овог пројеклта проистекао је пројекат Српска дечја дигитална библиотека представља јединствену дигиталну колекцију од 130 дечјих књига из српске књижевности. Национални уређивачки одбор, састављен од професора дечије књижевности и библиотекара, одабрао је књиге за децу узраста од 3 до13 година које по свом садржају, уметничким, историјским и књижевним вредностима представљају врх српске дечје књижевности (Chen и Bao 9). Пројекат је реализован у НБС 2004. године, књиге су доступне онлајн у пдф формату преко сајта НБС од марта 2005. године, а на TEL портал су постављене почетком 2006. године. Све дигиталне књиге су у боји и 
представљају дигиталне копије оригиналних штампаних књига. Издавачи из Србије су сарадници НБС у овом значајном националном пројекту, јер су Библиотеци уступили ауторска права за постављање целокупних књига у пуном тексту на Интернет презентације НБС и TEL-a. Све књиге појединачно су претраживе преко портала TEL-a, јер се у централном регистру Европске библиотеке налазе библиографски записи за сваки наслов.

Пројекат Гутенберг (PG - Project Gutenberg) ${ }^{11}$ је пројекат који је започео Мајкл Харт 1971. године, са циљем да све књиге које су у јавном власништву пребаци у електронски облик. То је урадио са два циља:

- да их се на тај начин сачува (јер папир труне),

- да буду доступне преко интернета свакоме кога занимају.

Пројекат Гутенберг обраћа се широкој бази корисника која укључује одрасле, децу и студенте. Има афлијације у Аустралији, Канади и Европи и др, са којима блиско сарађује.

Октобра 2007. године, доступно је преко 22 хиљаде наслова. На пројекту раде многи волонтери и свако ко жели, може да се прикључи пројекту. Да би неко учествовао у пројекту не мора имати ни књиге, ни скенер, ни софтвер оптички читач карактера (OCR - Optical Character Reader), довољна је добра воља. Године 2000. Чарлс Франкс покренуо je Projekt Gutenberg Distributed Proofreaders интернет странице, путем којих се може онлајн помоћи пројекту (Budzise-Weaver, Chen и Mitchell 225-226). У претраживачу (пошто се региструјете), појавиће се прозор у коме се види скенирана слика странице, а доле препознат текст. Крајем 2004. године пројекат је имао око 14.000 чланова, а они дневно „одраде“ просечно 5.000 страница. Са пројекта се преузима 2.000.000 књига месечно.

Прве књиге су углавном на енглеском језику. Како пројекат покренут у Сједињеним Државама, је фокус је био на публикације енглеског говорног подручја. Вишејезичност је почела 1997. године. Почетком 1998. године, каталог је имао неколико наслова на француском (10 наслова), немачком, италијанском, шпанском и латинском.

У фебруару 2004. године, било је публикација на 25 језика. У јулу 2005. године, било је радова на 42 језика, укључујући ирокешки ${ }^{12}$, сан-

11 Пројекат Гутенберг, http://www.gutenberg.org (приступљено 25.02.2016)

12 Језик, односно језици Ирокеза припадају породици ирокешких језика, породици која је добила име по њима. Највећу сродност постоји између језика мохок и онеида 
скрита $^{13}$ и језик Маја. Седам „главних“ језика (са више од 50 књига) били су енглески, француски, немачки, фински, холандски, шпански и кинески. У децембру 2006. године, било је књига на 50 језика. Број „главних“ језика повећан је за још три: италијански, португалски и тагалог. У априлу 2008. године, било је књига у 55 језика, са једанаест главних језика (додат је латински). Следећи је есперанто језик ${ }^{14}$ са 45 књиге, а затим шведски са 40 књига (Lebert 10). Тренутно Пројекат Гутенберг нуди колекције књига на 60 језика, које укључују 28,791 књига на енглеском, 1,685 на француском, 718 на немачком, 544 на финском, 501 на данском... (Budzise-Weaver, Chen и Mitchell 226).

\section{Сарадња: Пројекти и системи}

Док су библиотеке традиционално радиле заједно у кооперативним пројектима каталогизације, музеји са јединственим колекцијама често склони да раде независно једни од других. У изградњи дигиталних библиотека, сарадња је неминован јер захтева вештине из разних области (нпр. из информатике библиотекарства, архивистике, музеологије и уметности) да се изгради дигитална библиотека и додатне вештине, као што су лингвистика, обраду природног језика, или проналажење информација које ће бити потребне у случају вишејезичних дигиталних библиотека.

Конференција националних библиотека Европе (CENL Conference of European National Librarians) ${ }^{15}$ основана је неформално 1987. године у Португалу, на састанку директора неколико националних библиотека Европе. Од 1999. године регистрована је у Холандији као фондација 45 националних библиотека из 43 европске земље

и кауга и сенека. Остали језици породице су хјурон, или вајандот, сускехана, ири, чероки, тускарора, мехерин, нотавеј и дијалекти других мањих племена

Санскрт или санскрит је класични језик индијске књижевности. У Азији има статус сличан латинском и грчком језику у Европи. Свети списи хиндуизма, као и ммахајана и вађрајана будизма састављени су на санскриту.

14 Есперанто је плански креиран језик предложен за међународни језик створен да би олакшао и демократизирао комуникацију међу људима различитих говорних подручја и ултура. Прву уџбеник објављен је 1887. године у Варшави, од стране пољског лекара Лазара Лудвига Заменхофа под именом „Dr. Esperanto“ (доктор који се нада), што је касније постало и име самог језика.

15 Конференција националних библиотека Европе, http://www.cenl.org (приступљено 27.02.2016) 
(Италија и Русија имају по две библиотеке чланице). CENL делује по холандском законодавству, има свој статут и остале пратеће правне документе. Током двадесетогодишњег постојања CENL-a, националне библиотеке Европе заједнички реализовали многе значајне пројекте:

Gabriel - Gateway and Bridge to Europe's National Libraries Капија и мост ка европским националним библиотекама;

MACS - Multilingual access to subjects - Вишејезички приступ предметима помоћу повезивања предметних одредница на енглеском, француском и немачком језику;

VIAF - Virtual International Authority File - Virtuelna međunarodna normativna datoteka (Normativne datoteke imena i višejezičnosti);

MSAC - Multilingual Subject Access to Catalogues of National Libraries - Вишејезички предметени приступ каталозима националних библиотека;

Web Harvesting - складиштење шеб информација у националним библиотекама Европе;

TEL-ME-MOR - The Europen Library: Modular Extensions for Mediating Online Resources - пројекат чији је циљ да потпуно укључи у Европску библиотеку националне библиотеке нових чланица Европске уније (Voldering и Ljubanović 27-33).

\section{Проблеми и изазови}

Прелазак преко језичких баријера није једини изазов вишејезичних дигиталних библиотека. Додатни ргоблеми и/или изазови се односе на: управљање подацима и приказ информације и интероперабилност (повезивање између система).

\section{Језичка баријера}

Специфичност о вишејезичности дигиталних библиотека је да омогући претрагу информација на два или више различитих језика. Постизање овог подвига захтева прелазак језичке баријере да потребна информација (упит) одговара садржају (документ) различитих језика. Постоје многе опције за прелазак са једног језика на други. Може се превести упит на језик документа, може се превести документ на језику упита, могу се превести и упит и документ у тзв. међујезички 
приказ. Постоји и могућност превода метаподатака. Уместо да се преводи цео документ, много је ефикасније да се преведе запис метаподатака. Овај приступ је посебно погодан за збирке слика и других не текстуалних материјала који имају само описе на нивоу метаподатака.

Међујезичко проналажење информација, које се одржава у вишејезичним дигиталним библиотекама, захтева прелаз језичке баријере. Грешке уведене током превода негативно утичу на резултате претраге вишејезичних дигиталних библиотека. Три фактора проузроковати грешке у преводу: недостатак превода техничких термина, акронима; погрешног разбијање не композитних фраза у преводу, и додавање више превод чула речи за превод. Проблеми прелаза језичке баријере су најчешће повезана са превођењем ресурса. Упити имају тенденцију да буду дуги само неколико речи и, када један или више речи не могу бити преведене јер се не појављују у речнику, преузимање неће успети. Истраживачи самостално претаржују и преводе, и те резултате превода додају у вишејезични речник (Diekema 5).

\section{Управљање подацима}

Управљање репозиторијумима и складиштење садржаја и метаподатака представља изазов за све дигиталне библиотеке и има одређене аспекте који компликују ствари за вишејезичне дигиталне библиотеке. Инструкције и форме метаподатака треба да буду преведени на различите језике и да буде разумљиво корисницима. Интерфејс дигиталних библиотека, такође, треба да буду преведени на језике које подржава библиотека, процес познат као интернационализација и локализација. Индексирање вишејезичних документ је такође изазов јер сваки језик има различите карактеристике и правила за одлучивање између термина садржаја. Додатни проблеми настају када се користи Оптичко читање карактера (Optical character reader - OCR) на документима, посебно за не латинични скуп карактера.

\section{Приказивање}

Приказ текста на екрану рачунара захтева знакова (слова или пиктограми) који ће се представљени као кодови у рачуна- 
ру. Овај процес се назива кодирање карактера и неопходан је за читљивост, обраду текста, као што је индексирање, и да текст буде претражив. Постоји збуњујући број кодирање шеме на располагању, али најраспрострањенији кодирање на Интернету је UTF-8 Unicode кодирање. Према Unicode конзорцијуму, Unicode може представљати било какав знак било ког писаног језика. Софтвер за дигиталне библиотеке, као што су Greenstone, подржавају не-Латин сет карактера. Пошто сви програми за кодирање не могу да се користе заједно, а нису сви језици заступљени у неком од њих, вишејезичне дигиталне библиотеке се суочавају са тежким изазовом у проналажењу одговарајуће шеме кодирања. (Diekema 7).

Интероперабилност је способност хетерогених система, да раде заједно што је могуће боље, како би информације могле да буду размењиване, односно како би кориснику биле на располагању, а да при томе нису потребне додатне операције за споразумевање два система. Изазов је да се преведе појединачни кориснички упит на језике свих библиотека учесница, активирати их ка свакој библиотеци и, коначно, комбиновати све скупове резултата у једној листи. Сарадња је нераскидиво повезан са интероперабилности. Рад на вишејезичкој, мултикултуралној, и понекад чак вишегенерацијској области, представља изазов за Међународну дечију библиотеку. Слично томе, пројекту Европска библиотека не само да је потребна интероперабилност на техничком нивоу, већ и на друштвено-политичком и семантичком. Семантичка интероперабилност понекад се јавља када се комбинују различите библиотеке са својим различитим тезауруси у једни и доводи до интелектуалних и техничких изазова спајања различите структуре знања (Diekema 8).

\section{Закључак}

Дигиталне библиотеке су драгоцена средства информација за своје кориснике и они морају бити пројектовани на разноврсне популације, без обзира на њихов језик. Снабдевање вишејезичним интерфејсом за комуникацију на матерњем језику, корисницима омогућава да брзо идентификују и користе релевантне информације у дигиталној библиотеци. 
Овим радом се показује да постоји ограничен број постојећих вишејезичних дигиталних библиотека, али да њихов број расте. Креирање вишејезичних дигиталних библиотека је плод сарадње различитих организација и људи из различитих области експертизе, тиме омогућавајући корисницима да претражују ресурсе и да се пређе језичка баријера, што може бити изазов у зависности од језика и доступност ресурса.

Вишејезичне дигиталне библиотеке, омогућавају корисницима да приступе дигиталним колекцијама користећи различите језике, дају портал за јачање индивидуалних култура, промовисању различитости, и побољшање глобалне информационе инфраструктуре истицањем незаступљених језика у световним заједницама. Они отварају могућности за шири међународни развој, разумевање и сарадњу.

\section{Литература}

Bilal, Dania, and Imad Bachir. „Children's interaction with cross-cultural and multilingual digital libraries. II. Information seeking, success, and affective experience." Information processing \& management 43.1 (2007): 65-80.

Borgman, Christine L. "Multi-media, multi-cultural, and multilingual digital libraries." $D$ Lib 3.6 (1997).

Budzise-Weaver, Tina, Jiangping Chen, and Mikhaela Mitchell. „Collaboration and crowdsourcing: the cases of multilingual digital libraries." The Electronic Library 30.2 (2012): 220-232.

Chen, Jiangping, and Yu Bao. „Information access across languages on the Web: from search engines to digital libraries." Proceedings of the American Society for Information Science and Technology 46.1 (2009): 1-14.

Clinchant, Stephane, and Jean-Michel Renders. "Multi-language models and meta-dictionary adaptation for accessing multilingual digital libraries." Workshop of the Cross-Language Evaluation Forum for European Languages. Springer Berlin Heidelberg, 2008.

Clough, Paul, and Irene Eleta. „Multilingual Information Access in Digital Libraries." Multimedia Storage and Retrieval Innovations for Digital Library Systems (2012): 85.

Diekema, Anne R. "Multilinguality in the Digital Library: A review." The Electronic Library, vol. 30, no. 2, 6 Apr. 2012, pp. 165-181.

Larson, Ray R., Fredric Gey, and Aitao Chen. „Harvesting translingual vocabulary mappings for multilingual digital libraries." Proceedings of the 2nd ACM/IEEE-CS joint conference on Digital libraries. ACM, 2002.

Lebert, Marie. „,The Project Gutenberg EBook of Project Gutenberg (1971-2008)”. Project Gutenberg eBook, October 26 (2008).

Mizera Pietraszko, Jolanta. "Model design of user interfaces for multilingual digital libraries." TCDL Bulletin 3.3 (2007). 


\section{Филологија културе}

Vassilakaki, Evgenia, and Emmanouel Garoufallou. "Multilingual Digital Libraries: A review of issues in system-centered and user-centered studies, information retrieval and user behavior." The International Information \& Library Review 45.1-2 (2013): 3-19. Voldering, Brita, and Gordana Ljubanović. „Povezivanje sa korisnicima: Evropa i višejezičnost." Glasnik Narodne biblioteke Srbije 1 (2006): 23-36.

Конференција националних библиотека Европе , http://www.cenl.org

Пројекат Гутенберг, http://www.gutenberg.org

Међународна дечија дигитална библиотека, http://en.childrenslibrary.org

Светска дигитална библиотека, https://www.wdl.org/en/

Европска библиотека, http://www.theeuropeanlibrary.org/tel4/

Колекција Еуропеана, http://www.europeana.eu/portal/en

The Creative Commons, „CCO“, https://creativecommons.org/choose/zero/

Europeana Collections 1914-1918, „About“, http://www.europeana-collections- 1914-1918.eu

Assocciation of European Research Libraries, „A Gateway to Europeana Newspapers", http://www.europeana-newspapers.eu

Europeana Libraries, http://www.europeana-libraries.eu

Europeana Professional, "Europeana Awareness", http://pro.europeana.eu/project/europeana-awareness

\section{Bojana Trebinjac}

\section{MULTILINGUAL DIGITAL LIBRARIES}

\section{Summary}

Language is critical to bridging the gaps between cultures and offering a window for international collaboration. Multilingual digital libraries, which allow users to access digital collections using different languages, provide a portal for strengthening individual cultures, promoting diversity, and enhancing global information infrastructure by highlighting underrepresented languages in worldly communities. As a natural consequence of increasing globalization and the advent and growth of the Internet, digital libraries have been created that not only cross borders, but also languages.

This article examines multilingual digital libraries: Project Gutenberg, The European Library, dLibra, eLibrary Goethe-Institut Belgrad, Digital National library of Serbia, Digital Matica srpska Library. This examination used a framework derived from digital library evaluation practice. The missions, goals, funding, partners, users, collections, services, and technologies of these digital libraries were analyzed to present their key multilingual features.

Key words: digital library, e-philology, projects, collections, electronic libraries 